\title{
Czeskie przygody polskich oświeconych. Podróże Polaków do Czech w XVIII wieku
}

Paweł Kaczyński 


\section{Paweł Kaczyński}

\section{Czeskie przygody polskich oświeconych. Podróże Polaków do Czech w XVIII wieku}

W

XVIII wieku polskie opisy podróży wzbogacają się o dwie odmiany gatunkowe. Jedna to związany z podróżani przymusowymi dziennik lub pamiętnik wygnańca (na przykład wspomnienia Józefa Kopcia z Syberii czy slynne pamiętniki Maurycego Beniowskiego), druga to diariusz podróży naukowej, której przykładem w piśmiennictwie europejskim może być lojage anx régions équinoxiales du Nomean Continent Aleksandra von H Iumboldta. W diariuszu takim

glównym przedmiotem zapisu staje się nie ciąg wydarzeń historycznych i nie sprawy osobiste autora, lecz dokumentacja naukowa, oglądanie świata pod kątem potrzeb i upodobań badawczych'!

Tak się składa, że trzy polskie dzienniki tego typu - Franciszka Ksawerego Bohusza, Stanisława Poniatowskiego i Stanisława Staszica, są jedynymi w polskim piśmiennictwie podróżniczym XVIII wieku zawierającymi obszernicjsze partie dotyczące Czech.

W epoce Oświecenia ziemie Korony Swiętego Wacława nie byly bowiem dla Polaków częstym celem podróży. Jeśli już pojawia się ich opis, to raczej zwięzły i schematyczny, jako kraju, który jest tylko etapem w podróży do imnych miejsc. Jedna z najczęściej wykorzystywanych tras wojażu do Wiednia, a stamtąd przeważnie dalej — do Włoch (oraz droga powrotna), od najdawniejszych czasów prowadzila przez Śląsk Cieszyński i Morawy. Stąd stosunkowo wiele wzmianek polskich podróżników o tych ziemiach, ale rzadko przekraczają one objętość paru zdaí, zwłaszcza w spisywanych ex post paniętnikach.

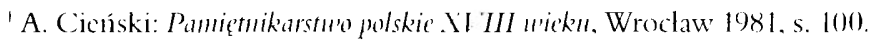


Nicktóre z wrazeń trafily do literatury. Ignacy Krasicki odbył podróż tym szlakiem w 1759 roku. Nie zachowała się jego wlasna relacja, ale w Mikotaja Doświadczýnskiego przypadkach bohater udaje się do Wiednia tą samą drogą. Oczywiście naiwne spostrzeżenia młodego Mikołaja, dotyczące na przyklad mocy morawskiego piwa, nie są zapewne powtórzeniem tego, co myślał podczas swej podróży świeżo wyświęcony ksiądz Krasicki, ale być może pochwała stanu dróg i podziw dla ufortyfikowanego Olomuńca odpowiadają zapamiętanym wrażeniom samego autora.

Nie tylko drogi morawskie budziły uznanie naszych podróżników. Podobnie jak w staropolskich opisach, także w epoce Oświecenia - teraz zapewne pod wpływem idei fizjokratyzmu - zwraca się uwage na urodzajne ziemie, rozwój upraw, porządek we wsiach i miastach. Jan Nepomucen Kossakowski, późniejszy biskup wileński, przejeżdżając w roku 1781 przez Morawy, notıje:

Jak tylko mogą być najlepsze, Morawy mają grunta, obfitujące w zboże, len i wino ordynaryjne. Od Mariahilft najpiękniejsze zaczynają się winnice².

Franciszek Karpiński:

Przez Opawę, Ołomunicc, Bryn w Morawii (...) wszystkie wsie, miasteczka i karczmy uporządkowane, co tylko wygoda chciała, dostarczały; drogi najlepiej utrzymane podróż najmilszą czynily ${ }^{3}$.

Julian Ursyn Niemcewicz:

Jechaliśmy przez Racibórz, Cieszyn, Opawę i Brno. Z powiększającą się drogą tą uprawą roli, jej bujnością, zamożnością miast rosło podziwienie mojet.

Podziw podróżników rośnie zazwyczaj właśnie w miarę posuwania się na południe. Nadjeżdzający z przeciwnego kierunku, im bliżej Śląska Cieszyńskiego, tym więcej notują uwag krytycznych:

cała kraina od Šteruberku aż do granicy polskiej jest źle urządzona i w nieładzie. Droga wszędzie okropna, a mosty niebezpieczne (...) Caly ten kraj jest bardzo wesoly, gleba żyzna, dorodność drzew i roślin świadczy o ogromnej bujności... - jednak cala ta piękna kraina jest wyludniona (...), wsie, przez które się przejeżdza, są niewielkie i ubogie, najlepsze grunta leżą odłogiem.

2J. N. Kossakowski, Dziennik mego ₹ycia = r. 1781, ,Biblioteka Warszawska“ 1895, t. 2, s. 457.

${ }^{3}$ F. Karpiński. Historia mego wiekn i ludzi, z którymi zytem, opr. R. Sobol. Warszawa 1987, s. 61.

'J. U. Nicmccwicz, Pamiętniki calsóu' moich, opr. J. Dihm. t. 1. Warszawa 1957, s. 154. 
Niektóre są uprawiane, ale niedbale. Bydło z powodu zaniedbania jest małe, brudne i cherlawe'.

Potwierdzeniem zależności ocen od punktu odniesienia (dla jadących na poludnie była nim Polska, dla powracających — raczej zwiedzanc wcześniej kraje, zwłaszcza niemieckie) może być porównanie opisu pierwszego miasta „cesarskiego” za granicą — Bielska. Wracający z zagranicznych wojaży Michał Jerzy Mniszech widzi je jako „dość duże, ale niezıniernie brudne”, dziesięć lat później Bolıusz, jako „miasteczko” ledwie zasługujące na tę nazwę, z wąskimi ulicani ${ }^{7}$. Wyjeżdżający natomiast z Polski Karpiński, dla którego byto to pierwsze miasto zagraniczne, po latach wspomina:

postrzegłem w Bilitz zaraz inszy porządek, wiele domów miejskich murowanych i ochędóstwo wszędzie największe; wtenczas kiedy my jak o dobro narodu swego, tak okolo miast i domów naszych niedbali’.

Należy zapewne wziąć poprawkę na dystans czasowy (który mógł spowodować przesumięcie wstecz spostrzeżeń z dalszych etapów podróży) i cel moralizatorski tej oceny, ale jakieś rzeczywiste wrażenie chyba legło u jej podstawy.

Dla wjezdżającego do Czech inmą droga Stanistawa Poniatowskiego różnica „pólnoc — południe" wygląda zupełnie inaczej. Bo też północa jest w jego przypadku Dolny Śląsk - zagospodarowany i uprzemysłowiony. Natomiast „za Frydlandem [Mieroszów] granica czeska, ale kraj smutny, blechów i industryi tak wiele nie widać, tylko ubóstwo gminu”, drogi też od razu gorsze". W drodze powrotnej z Wiednia przez Morawy zauwazy z kolei „w całym tym kraju aż do granicy polskiej mizerniejsze budowle jak w innych częściach Niemiec" (s. 229). W miarę posuwania się na poludnic i zachód (czyli do krajów rdzennie niemieckich) poziom cywilizacji się podnosi. Jeśli zaś chodzi o Śląsk, to Poniatowski mimochodem potwierdza weześniej cytowane opinie:

graf Gurzyúski, który ma dobra w Szląsku cesarskim i pruskim, mówil, iz równej dobroci mając w obu ziemie, więcej ma daleko w pruskim intraty, i że rząd pruski lepszym jest dla szlachty (s. 193);

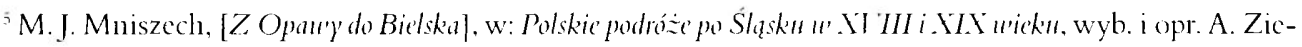
liński, Wroclaw 1974, s. 39-40.

"Ihide'm, s. 40 .

${ }^{7}$ F. K. Bohusz, Diariusz woja $\div 11 \ldots$ 1777-1778. „Kronika Rodzinna” 1885, s. 207 (pozostale cytaty za tym wydanicm z paginacją w nawiasic).

${ }^{*}$ F. Karpiński, op. cit., s. 60.

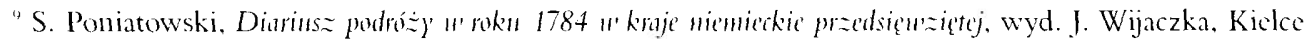
2002. s. 165-166 (pozostale cytaty za ty'm wydaniem z paginacją w nawiasic).
} 
a w Raciborzu sam stwierdza:

industryi dalcko więcej niźli w Szląsku cesarskim (s. 231).

Z opinii polskich podróżników wynika ostatecznie pewna gradacja regionów: kraje cesarskie (Śląsk Cieszyński, Morawy, Czechy) stoją gospodarczo wyżej od Polski, ale nizej od Śląska pruskiego.

Jeśli jednak wziąć pod uwage inne czynniki, sprawa się komplikuje. Wrocław pod panowaniem pruskim przedstawia się Bohuszowi smutno, co prawda "lud caly handlem lub rzemiosłem zatrudniony”, ale ,nie zna prawie rozrywki, od której i akcyzę płacić by musiał”. Cóż z tego, że eks-jezuicki „kościól i colleginum cum unimersitate są wielkie i wspaniałe”, skoro w obserwatorium astronomicznym brak instrumentów, a biblioteka „bardzo nikczemna” (s. 40). Do tego „zdzierstwa, przykre rewizje i twardy ton pruski”, sprawiają, że z ulgą przekracza się granice Saksonii (s. 41) ${ }^{10}$.

Trasa przez Sląsk Cieszyński i Morawy, a także pobyt w Czechach nie powodowały szoku kulturowego na pewno pod jednym względem - językowym. Wrażenie swojskości pojawia się nawet w bardzo pobieżnych relacjach. Dotyczy to zarówno pogranicza, gdzie .język z czeska - polski“" ", ,a lud ledwo rozumie po niemiecku”'?, jak i terenów rdzennie czeskicl.

Kossakowski dostrzega, iż ,język morawski malo się różni od polskiego, ale po wsiach tylko jest używany, w miastach niemieckim mówią". Wspólnota kulturowa polega nie tylko na językowym pobratymstwie. Lud morawski „pobożny, corocznie w wielkiej gromadzie odwiedza Częstochowę"13. Bohusz podczas pobytu w Pradze zauważa:

mowa czeska, której lud używa, tak podobna do polskiej, że jej nie uczywszy, dość dobrze się rozmówić można, w zapomnienie wprawiła, że byłem za granicą (s. 98).

Karpiński, wspominający w spisywanyım po latach pamiętniku podróż do Wiednia, niewiele pamięta na temat Czech, ale podkreśla:

\footnotetext{
1" W czasach. których dotyczą cytowane opisy, wiçksza część Śląska nawet formalnie nie należała już do Królestwa Czeskicgo. Ze względu na temat niniejszego szkicu w ograniczonym zakresic uwzględniany wiçc polskie relacje ze Śląska pruskiego - wtedy tylko. gdy są one ctapem podróży do Czéch i stanowią jakiś kontekst dla opisu zicm Korony św. Wachawa. Dlatego pomijanny na przyklad podróz Staszica z $180+$ roku (zob. przypis nast.) i inne relacje zebrane w cytowancj antologii A. Zielińskicgo.

"S. Staszic, Dziemmik poidrózy' 1789-18115, wyd. Cz. Leśnicwski. Kraków 1931. s. 15 (pozostale cytaty za tym wydanicm z paginacja w nawiasic).

12 M. J. Muiszech, op. cit.. s. 38.

${ }^{13}$ I. N. Kossakowski, op. cit.. s. 457.
} 
Przez Opawę, Ołomminiec, Brno w Morawii, wszystkie te kraje naszych dawnych Slawianów przejeżdżając, wszędzie z pospólstwem moim językiem rozmawiałem się ${ }^{\text {th }}$.

Stanisław Staszic zanotował, że Brno ma ,teatr niemiecki. Narodowego, tj. w języku morawskim nie ma, bo i język rodowity już ginie" (s. 20). W innym miejscu wskazuje na przyczynę, mówiąc o szkołach: „Dzieci pospolicic gadają po czesku, ale nie wolno uczyć, tylko po niemiecku" (s. 16). Trafnym podsumowaniem tego problemu jest zdanie z pamiętników Niemcewicza, opisującego po latach swój emigracyjny wyjazd do Wiednia w roku 1793:

Z żalem widziałem, jak Czesi, pobratymcy nasi, usiłowaniem rządı coraz bardziej przemieniają się w Nienców; szlachta już nie umie ojczystego języka naszego. Niestety — ponyślałem sobie, tak będzie i z nieszczęsną Polską naszą ${ }^{15}$.

To poczucie słowiańskiego pobratymstwa polsko-czeskiego, najsilniej wyrażone przez Karpińskiego i Niemcewicza, pobrzmiewa jednak i w pozostałych relacjach podróżniczych, przede wszysthim właśnie w stwierdzeniach o podobieństwie języków.

Tradycyjuą trasą polskich wojażerów podróżował do Wiednia Stanislaw Staszic. W przeciwieństwie jednak do zwięzlych relacji większości z nich, jego zapiski - diariusz podróży naukowej - zawierają bogatszy opis Moraw. Staszica interesuje nie tylko gospodarka, ale i życie społeczne, kultura, oświata, administracja, ustrój. Niezwykle rzadkie są tu anegdoty, brak też tak częstych w innych pamiętnikach ciekawostek obyczajowych: jeśli się nawet pojawiają, to Staszic robi wszystko, by odebrać im atrakcyjność, sprowadzić do pozionu suchej informacji, przythoczonej danymi statystycznymi. Jedząc obiad w oberży księcia Kaunitza gdzieś między Vyškovem a Brnem, nie informuje nas o menu, ale o wysokości czynszu, jaki gospodarz płaci księciu i jakie ma obowiązki wynikle z umowy. Nawet nie wiadomo, na jakiej sztuce był w teatrze w Brnie, zbywa grę aktorów jednym epitetem, za to skrupulatnie wylicza ceny biletów w zależności od miejsc.

Sam autor mimo to rysuje się calkiem wyraziście, nie tylko jako bardzo skrupulatny obserwator, ale czlowiek o ustalonych poglądach. Zdarza mu się emocjonalıy komentarz, gdy wskazuje przykłady krzywdy niżsych warstw społecznych lub nieprawidlowości ustroju, choć to raczej oburzenie na system niż współczucie dla konkretnego czlowieka ${ }^{\text {th }}$. Staszica interesują przyczyny, dla których cale grupy społeczne bywają upośledzone. Stara się odkrywać źródła zamożności lub biedy, uwzględniając wszelkie czymniki: od geograficznych po polityczne. To ten sam punkt widzenia fizjokraty, który stanie się zwornikiem jego

\footnotetext{
${ }^{1+}$ F. Karpiński, op. cit., s. 61.

${ }^{15} \mathrm{~J}$. U. Nicncewicz, op. cit., t. 2. Warszawa 1957. s. 61.

16 Por. B. Szacka, Stanistaw Staszic. Warszawa 1966, s. 54 i nast.
} 
poglądów wyrażonych w Rodzie ludzkim. Podróże dostarczyły Staszicowi materiału, który wykorzystał, kreśląc ogólną wizję rozwoju ludzkości.

Motywem powracającym wielokrotnie jest porównanie sytuacji w Czechach do warunków polskich. Oprócz stwierdzeń neutralnych, jak na przykład:

Odmiany tego kraju [Śląska Cieszyńskiego] ogólnie od naszego tym się różnią: wsie rozrzucone, małe, każdy rolnik na swoim gruncie mieszka. Po polach widać ich domy odosobnione (s. 14) -

pojawiają się często porównania wartościujące:

Miasta są nierównie od naszych piękniejsze, ludniejsze i rzemieślnikiem obsiadle... (s. 14-15);

Budynki wlościan nierównie porządniejsze od naszych... kominy wszędzie. Okna od naszych większe. Szkółki po wszystkich wsiach (s. 15).

Nie tylko na Śląsku, także na Morawach czyni podobne spostrzeżenia:

Wsie już nie rozrzucone, ale wszystkie są w jednym miejscu zabudowane, jak u nas w Polsce. Ale domy whościan porządne (s. 16).

Stwierdziwszy tylekroć lepszy stan czeskiej wsi, Staszic zastanawia się z natıkową dociekliwością nad jego przyczynami:

Stan włościan jest lepszy i porządnicjszy. Przecież gruntu ani więcej, ani lepszego od polskiego wościanina nie posiadają, ani wolności nie mają, bo są poddani i pańszczyznę robią. Również mogą być krzywdzonymi od pana, jak nashuchałem się od ludzi... Cóż więc za przyczyna tej lepszości stanu chłopa? —Że go Żydzi nie rozpoją, i że okoliczność więc na sprzedaż i zarobek łatwy. Pijaństwa nigdzie po wieśniakach nie uważałem. Niedzielne zabawy parobków wiejskich bywają kręgle i inne gry ręczne. Tylko jednego w całej dotąd drodze trafiło mi się widzieć pijanego czlowieka... (s. 17).

Z kolei przyczynę zamożności miast widzi Staszic w lepszym ich ustroju:

Miasta ludne i rzemieślnikienn napełnione, że sprawiedliwość i obronę prędzej znajduje (s. 17);

Zdziwiony, jakim sposobem tutejsze miasta są tak piçkne i ludne, szukałem przyczyn: bo są wolne, a pelne fabryk... i handel wnętrzny mają calkiem wolny... Dziedzicowi tylko czynsz mały płacą z tytułu jego dziedzictwa (s. 18). 
Ta odmienność ustroju miast w porównaniu z polskimi, zduszonymi w wolności politycznej i ekonomicznej przez szlachtę, jest dla Staszica oczywista. Takie miasta są też dobrym odbiorcą płodów rolnych, co, jak wyżej powiedziano, wpływa na sytuację wsi. Staszic, jako fizjokrata, dostrzega wzajemne zależności między różnymi czynnikami społecznymi i ekonomicznymi i ich wpływ na sytuację ogólną.

Nie znaczy to jednak, ze polski podróżnik jest bezkrytycznym zwolennikiem absolıtyzmu w wersji józefińskiej, pod którego rządami rzemieślnik, a czasem i chłop, bardziej są ludźmi niż w Polsce. Denerwują Staszica na przyklad przerosty administracji i nadmierna waga, jaką wladza absolutna przywiązuje do armii. W Brnie z jednej strony odnotowuje z uznaniem założenie przez Józefa II parku publicznego, ale inne postępki cesarza nie budzą jego entuzjazmu:

Szedtem koło domu po jezuitach dla gubernium zabranego, z tym napisem Josephus II dedit patriae, kiedy sobie ponyślilem: kto, co i komu daje? Napis pełen słów bez znaczenia (s. 20).

Według Staszica Józef II, odbierając budynek jezuitom, nie oddał go ojczyźnie, ale swym urzędnikom, równie zbędnym jak zakonnicy. W reformach józefińskich nie podoba się Staszicowi to, że omnipotencja i nadmiar kleru zostały zastąpione omnipotencją i nadmiarem urzędników i żołnierzy.

Doceniając więc poziom cywilizacyjny (zwłaszcza gospodarczy) ziem czeskich, nie pomija Staszic ujemmych stron panującego porządku. Najwymowniej świadczy o tym jego uwaga o twierdzy Spilberg:

Jest to miejsce okropne, katusza despotyzmu. Ofiary przemocy często bez sądu jęczą w lochach podziemmych (s. 20).

W swym dążeniu do wszechstronnego zobrazowania stanı zwiedzanych krain, wskazując na przykłady pracowitości i gospodarności, nie pomija też cech negatywnych, które, zgodnie ze swymi poglądami społecznymi, przypisuje głównie wyższym warstwom — jak we wspomnieniu z Brna:

Wieczór przebyłem na assemblach u gubernatora Morawy. O 7-ej zjechali się goście i zaraz każdy ugodził swoich wspólników do gry. Nie wyszło pół kwadransa, już wszyscy zasiedli stoliki tak dalece, iż żadnej osoby nie pozostało do rozmówienia się. Ten zwyczaj jest skutkiem próżniactw. Każdy nudzi się, mówić także boi się. Więc bez zajęcia duszy marzą grą w karty swoje zmysły. Ta próżniacka zabawa ciągnie się do 9-ej godziny, o której znowu każdy wstaje, wychodzi i jedzie do domu (s. 20). 
Staszic także w swoim dziennniku jest wolnomyślny i antyklerykalny, w czym, jak wiadomo, nie przeszkadzala mu sukienka duchowna. Dowodem wysokiego poziomu cywilizacji na pograniczu śląsko-morawskim jest dla niego mała ilość kościołów. Z kolei widząc w okolicach Olomuńca wicle kapliczek i krzyży przydrożnych, ocenia lıd jako „dosyć zabobonny”. Arcybiskup Colloredo, którego spotkal po drodze, ,najwięcej odróżnial się od innych ludzi swoją zbytecznością, otyłością".

Przy wszystkich niedostatkach, jednak porównania sytuacji gospodarczej ziem czeskich i polskich wypadają na niekorzyść tych drugich. Widać tu często rozpaczliwe wręcz dążenie do dźwignięcia Polski z cywilizacyjnego zacofania i ubolewanie nad brakiem gospodarczej inicjatywy Polaków. Opisując na przykład szczegółowo pracę fabryczki koło Brna, produkującej tasiemki bawełniane, które eksportowane są w większej części do Polski, zadaje Staszic retoryczne pytanie: „Czylizby nie można rzeczy tak lichej i do robienia latwej u nas zaprowadzić?” (s. 21). Takie obserwacje i przemyślenia można uznać za przesłanki przedsięwzięć Staszica, które " progu XIX wieku zapoczątkowały ekonomiczne ożywienie na ziemiach polskich.

Pomysty na zaprowadzenie w Polsce niektórych ,industryi” pojawiają się także we wcześniejszym o kilka lat dzienniku Stanisława Poniatowskiego. Przemyślenia te wynikają zresztą z sondażowego charakteru wyprawy podjętej przez królewskiego bratanka ${ }^{17}$. Być może cel podróży wplynął na ksztalt zapisków, które mają charakter jeszcze bardziej techniczny niż dzienniki Staszica. Także zakres zainteresowań Poniatowskiego jest inny. Mniej interesują go kwestie spoleczne i polityczne oraz to wszystko, co można by nazwać moralnym wymiarem życia gospodarczego. Nie wchodzi, jak Staszic, w rozważania wiążące poziom rozwoju ekonomicznego z cywilizacyjnym w ogóle, a moralnym w szczególności. Bardziej jest obserwatorem niz interpretatorem. Porównania z rzeczywistością polską częściej są sugerowane niż wypowiadane wprost, gdy na przykład przelicza dochody dziedziców w Czechach z propinacji na złote polskie. Zwrot ,miasteczko dosyć podobne do polskich, jednak porządniejsze" to najdalej posunięta waloryzacja porównania. Zarazem dokończenie tego zdania: „i coraz, jako inne wszytkie, do lepszego stanu przychodzące” (s. 169) kryje w sobie pochwałę postępu, jaki dokonuje się na ziemiach czeskich pod rządami Józefa II. Radykał Staszic dostrzeże drugie oblicze oświeconego despotyzmu - Spilberg; Poniatowski ogląda z zainteresowaniem twierdze, ale nie wspomina o ich pozawojskowych funkcjach. Zwolennik porządku, także militarnego, całkowicie bezinteresownie przejmuje się dostrzeżonymi w Świdnicy objawani rozluźnienia dyscypliny garnizonowej w armii pruskiej. Nieznoszący Prusaków Bohusz nie byłby chyba tak obiektywny.

Dziennik Bohusza, najwcześniejszy z omawianych tu opisów podróży naukowych, jest najmniej z nich pedantyczny, najwięcej w nim za to uwag osobistych. Również ksiądz, jak Staszic, ale również bardzo „oświecony”, spogląda na zwiedzane miejsca inaczej niż staro-

17 Zob. S. Poniatowski. op. cit., s. XX. 
polscy podróżnicy, ale i inaczej niż Staszic i Poniatowski. Bohusz nie czuje się w obowiązku powiedzieć czegokolwiek o każdej mijanej wiosce. Jest też chyba mniej dociekliwy. Staszic na przykład nigdy nie usprawiedliwia się, że czegoś nie wie, bo nie znalazt kompetentnych informatorów, jak to się zdarza Bohuszowi. Bohusz bierze to, co mu wpada w ręce, ale stara się też o takie okazje. Z drugiej strony, miał chyba muiej możliwości wstępu do różnych miejsc niz Poniatowski, podróżujący niejako of icjalnie.

Mimo odmiennego stylu relacji, zdarza się Bohuszowi i Poniatowskiemu pisać o tym samym. Obaj analizıją system pańszczyźniany w Czechach i kwestię oczynszowania w kontekście sytuacji w Polsce. Obaj też zostawili w swych dzicnnikach jedyne w polskim podróżopisarstwie epoki Oświecenia opisy Pragi. Tutaj także wykazıją czasem podobne gusta i zainteresowania. Obu w zachwyt wprawia widok miasta z wysokości I Iradu, Petřina i ogrodów Lobkowica, obaj też zgodnic uznają, że Most Karola został zeszpecony ustawionymi na nim statuami. Zwiedzają te same zabytki - co zrozumiałe, bo są to największe atrakcje Pragi, do których już wtedy prowadzono każdego turystę — ale tu już prezentıją odmienne opinie. Młodszy o parę lat Poniatowski z uznaniem wyraża się o gotyckiej architekturze kościoła NMP przed Tynem i katedry św. Wita (s. 176, 182), gdy dla starszego Bohusza kościół katedralny jest „misternie, a razem gustownie stawiony” m i mo że "gockim gustem”. Architekturę innych świątyń praskich "gustem nienieckim” uważa za „mizerną”, woli „włoski gust” kościoła Krzyżowców z Czerwoną Gwiazdą.

Obaj podróżnicy dostrzegają wielkie bogactwo praskich świątyń, zarówno w sensie ich liczby, jak i wystroju. O ile jednak Poniatowski poprzestaje na suchym sprawozdaniu, ograniczając się co najwyżej do ocen w rodzaju: „bardzo piçkne”, „dosyć piękne”, „dosyć wspaniały”, albo „w złym guście”, o tyle Bohusz pozwala sobie na obszerniejsze sądy. Oto dla przykładı opis kaplicy św. Waclawa pióra Poniatowskicgo:

prawie cała jest kamieniani czeskiemi najrzadszymi wysadzana, z nich niektóre bardzo piękne, jako to sztuka duża chryzoprazu i dosyć piękna (s. 182);

\section{Bohusz:}

ściany wszystkie są wysadzone aspisem, ametystem, karnelinami, ale bez żadnego porządku i smaku. Wartość wielka jest materiałı, ale nic nie zaleca artysty (s. 73).

Gdy chodzi o kościoły, Bohusz ma wogóle więcej do powiedzenia niż Poniatowski. Szerzej i bardziej szczególowo rozwija wątek ich bogatego wyposażenia. Podaje na przyklad w czerwonych złotych wartość złotego krucyfiksu w katedrze. Z podziwem wypowiada się też o skarbcu w Lorecie, wspominając o słynnej monstrancji jako o ,najkosztowniejszej w Europie". W sumic 
nie wszystkie kościoły są i zewnątrz, i wewnątrz piękne, ale są wszystkie dostatnie w srebro, klejnoty, marmury, kości świętych. Chyba w Rzymie więcej. Nie ma kościola, gdzie by kilku przynajmmiej świętych zwłok nie miano (s. 72-73).

Ta ostatnia uwaga charakterystyczna jest dla wywodów Bohusza w sprawach religii. Jak już powiedziano wyżej, nie jest on, w przeciwieństwie do staropolskich podróżników, nabożnym pielgrzymem, lecz oświeconym sceptykiem. Co ciekawe jednak, różni się tym także od Poniatowskiego, który tego wątku w ogóle nie podejmuje. Sporo miejsca w Bohuszowym opisie Pragi zajmują bowiem sprawy relikwii i kultu, a zwłaszcza legend o cudach związanych z poszczególnymi kościołami i monumentami. Mówi o tym zwykle z ironią, jak o obecności relikwii św. Wojciecha w katedrze:

jest to cialo tego samego Wojciecha, którego Polacy z uszanowaniem chowamy w Gnieźnie. Nie wiem, co by to za nowy byl rodzaj replikacyi (s. 73).

W kościele św. Piotra i Pawla jego rozbawienie budzi wyobrażona w malowidłach historia zakładı, jaki mial pewien kapłan zawrzeć z diablem, o przyniesienie marmurowego słupa z rzymskiego kościoła na Zatybrzu. Szczątki tego słupa również oglądal:

Wstrzymać się ledwie od śmiechu można, widząc, jak niosącego ten słup szatana aniołowie z biczykami jak gończe niedźwiedzia ostanawiają i drogi mu spokojnie odbyć nie dopuszczają (s. 98).

Zaznacza jednak Bohusz, że „niebezpiecznie byloby wymówić się z tym, że ta historia jest bajką, i bajką niedorzeczną". Według naszego podróżnika bowiem

lud tu cały jest nabożny... Procesje, wystawienie Najśw. Sakramentu, benedykcyje ctc. prawie nieustanne. Nite ma dróżki malej, gdzie by kilka krzyżyków albo obraz jakiego świętego nie stal; nie ma ulicy, gdzie by przed jakim świętym przez noc nie paliła się lampa... Na kazania, na nieszpory we dni powszednie, ale święte Kościoła albo zakonu którego, rzemieślnik odbiega warsztatu, dom porzuca gospodyni, wszyscy do kościoła idą.

Bohusz ocenia te przejawy religijności w sposób typowy dla ówczesnych oświeconych duchownych. Stowa o ludzie praskim: „szczęśliwy, gdyby miał tyle pobożności, ile ma nabożeństwa” (s. 99), oddają sposób myślenia przedstawicieli oświecenia katolickiego, z ich niechęcią do tak zwanej religijności ludowej, nazbyt rozwiniętej obrzędowości, przerostów i wypaczeń kultu obrazów czy relikwii, zza których, jak twierdzili, nie było widać samego Boga.

Sprawa jest o tyle ważna, że ma znaczenie nie tylko z punktu widzenia religijnego, ale jest wedle Bohusza jedną z przyczyn upadku gospodarczego miasta: 
Miłość gnuśnoty, płaszczykiem pozonym nabożeństwa pokryta, thumy prowadzi po odpustach, kościołach, kongregacyjach. benedykcyjach, procesyjach, z uszczerbkiem nieodbitym własnego stanu obowiązków. Rzecz dziwna, jak dotąd to miasto nie upadło? Jakoż znacznie już spada, i naturalnie na koniec upaść musi (s. 177).

Bohusz wskazuje na objawy tego upadkı, jak na przykład niewidziana gdzie indziej liczbę żebraków, zadłıżanie się obywateli i świetną sytıację lichwiarzy.

Tłumacząc, że nie miał wielı dobrych informatorów, notuje jednak spostrzeżenia dotyczące kryzysu gospodarczego: wysokie podatki i cła, upadek rękodzieła i handlu, konieczność sprowadzania spoza miasta wielu artykulów, na które jednak z powodu ogólnego zubożenia zbyt jest niewielki, więc i zyski kupców i rzemieślników małe. Nie jest też Praga tak modna jak choćby Paryż, by mogła korzystać z napływu cudzoziemców. Miasto, mimo swej historycznej stoleczności, jest jednak prowincjonalne (brak rezydencji dworu), co też obniża jego atrakcyjność. Jest jednak największym ośrodkiem miejskim w Czechach, co sprawia, że mimo wszystko

cała szlachta czeska rezydencji innej w Czechach nie ma prócz Pragi, gdzie też aktualnie najpierwsze rodziny czeskie mają swoje palace (s. 178),

i dzięki temı na razie jeszcze miasto — „piçkne miasto” powiada Bohusz — jakoś się trzyma.

W Pradze więc polski podróżnik nie czuje kompleksu niższości, a raczej jakiegoś swojskiego ducha: nie tylko język o tym decyduje, ale stan ulic, które

są tak jak po miastach Polski czyste; kuchenne gnoje na ulice wyrzucane i wylewane, zarażaja powietrze i dlatego miasto całe, chociaż je wiatr ustawicznie przewiewa, w obloku i we mgle zawsze zostawać zdawa się.

Weltawa przypomina Wisłę tym, że „mętna, mułu wiele okolo mostu nanosi” (s. 98).

Takiego przedstawienia Pragi, jako żywego organizmu micjskiego z jego cechami specyficznymi, nie znajdziemy a Poniatowskiego. Rozmaitych informacji szczegółowych, także o miejscach, których Bohusz nie odwiedzil (na przykład Klementinum), nie traktuje bratanek króla jako przesłanek do budowania uogólnień.

Nie zachowat się niestety żaden opis Pragi pióra Ignacego Krasickiego, choć wiemy, że ten bawił nad Wettawą, i to dwukrotnie, jak świadczy o tym list z 31 sierpnia 1797 roku, w którym sekretarz poety Michalski opisuje bratu biskupa Autoniemu drogę do Karlsbadı i sam pobyt w uzdrowisku ${ }^{18}$. Już w 1795 roku poeta spędził tu na kuracji sześć tygodni

1" Korespondenga Ignacego Krasickiego, z papicrów Ludwika Bernackicgo wyd. i opr. Z. Coliński. M. Klimowicz, R. Woloszyński. red. T. Mikulski, t. 2, Wroclaw 1958, s. 683-685. Biograf Krasickiego Zbignicw Goliński wspomina tylko o pobycic w roku 1795 (zob. idem. Krasicki. Warszawa 200)2, s. 341). 
(28 maja - 22 lipca). Z tej podróży nie zachowal się jednak w bogatej korespondencji poety żaden list. W 1797 przed przyjazdem do Karlowych Warów Krasicki spędził parę dni we Wrocławiu, podejmowany przez znajomego sobie pruskiego ministra Hoyma, stantąd udał się do Pragi. Drogę wspomina sekretarz jako marną: „koleje ciasne, góry przykre i kamieni wszędzie pełno na tym trakcie". Przed Pragą zlamala się oś w karecie biskupa i koczem dojechat on do stolicy. Musiał ją już zwiedzać za poprzednią bytnością, bowiem Michalski pisze, że tym razem Krasicki „przez półtora dnia wypoczywał, bawiąc się nowym oglądaniem tego pięknego miasta". Niczego więcej jednak o pięknościach Pragi nie zanotował ani sekretarz, ani jego chlebodawca.

Wyprawy do wód w Czechach, zwłaszcza zaś do Karlsbadu, zdarzały się Polakom w osiemnastym wicku dość często. Ten fragment polskiej aktywności podróżniczej przebadal swego czası Marian Szyjkowski, opierając się na księgach gości uzdrowiska w XVIII i pierwszej polowie XIX wieku19 ${ }^{19}$. Kłopot w tym, że poza listą nazwisk i domysłami opartymi na źródłach pośrednich niewiele mógł o tych pobytach powiedzieć, nie pozostały po nich bowiem opisy.

Najwięcej miejsca poświęcil Szyjkowski pobytowi Ignacego Krasickiego w 1795 roku. Pomagając sobie fantazją i znajomością obyczajów karlowarskiego kurortu, stworzył zgrabną opowiastkę o wywczasach księcia biskupa, a spostrzegłszy, iż w tym samym czasie bawił na kuracji Goethe, spróbowal zrekonstruować to, co ewentualnie mógł jeden poeta myśleć o drugim. Szyjkowski uznal ten pobyt Krasickiego w Karlsbadzie za drugi z kolei, co w świetle dzisiejszej wiedzy o księciu poetów polskich wypadnie uznać za błąd. Wszystkiemu winien jeden czterowiersz nawiązujący do wizyty Krasickiego w Karlowych Warach (przetłumaczony zresztą na język czeski przez Čelakovsky'ego):

\section{W Karlsbadzie na studnię Neubrunn, gdzie pił wody ks. Krasicki, B. W.}

Ten, co kastalskie zdroje czerpał, gdy był młody,

Czerpal dziś z tego źródla karlisbadzkie wody.

O wody! Bądźcie mu tak, jak tamte skuteczne,

Dajcie mu życie dlugie, bo z tamtych ma wieczne.

Wiersz przypisywano Tomaszowi Kajetanowi Wegierskiemu ${ }^{20}$. Ponieważ zaś poeta ten wyjechał z kraju na zawsze - według tego, co sądzono w czasach Szyjkowskiego - w roku 1783, wiersz musiał więc powstać wcześniej. W rzeczywistości, jak ustalil J. W. Gomulicki" Węgierski wyjechał w roku 1779, a dostępne nam dane o biografii Krasickiego nie mówią nic o jego pobycie w czeskim uzdrowisku przed tym rokiem. Problem rozwiązu-

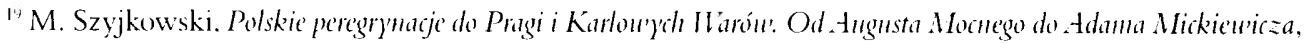
Bydgoszcz 1936. s. 13-31.

2"Zob. T. K. Węgierski, Pisma wierszém i prozq. wyd. K. Estreicher, Lwów 1882.

${ }^{21}$ Zob. Tabela biograficzna w: T. K. Węgicrski. Wiersze u'phane. opr. J. W. Gomulicki, Warszawa 1974.
} 
je założenie, ze to nie Węgierski byl autorem tego wierszyka i ze powstal on w związku z rzeczywiście pierwszym wyjazdem księcia biskupa warmińskiego do Karlowych Warów w 1795 roku.

Szyjkowski natomiast nic nie wiedzial o drugiej wizycie Krasickiego w tym kurorcie w roku 1797, o której many informacje prawie z pierwszej ręki we wspomnianym liście Michalskiego. Krasicki bawil w uzdrowisku tym razem krócej (od 21 sierpuia do 15 września), ale był „humoru najlepszego, wesół, bawi się dobrze i na wody się nie gniewa”. Być może ta ostatnia wzmianka świadczy, że poprzedniej kuracji nie znosil zbyt dobrze? Z tego samego listu dowiadıjemy się też o zamiarze zatrzymania się na parę dıi w Chebie i spróbowania tamtejszych „umacniających wód”, ale nie wiadomo, czy te plany zrealizowano.

Obszerniejszy opis Karlowych Warów (chyba też nieznany Szyjkowskiemu) wyszedl spod pióra Bohusza. Dość dokładnie i z naukową znajomością rzeczy przedstawił rodzaje i whaściwości źródel (nazywa je .Szprudel” i ..Mulbad” — to chyba ,Muhlbrumn”). Podaje informacje o historii i urządzeniu uzdrowiska, a także o gospodarczym wykorzystaniu nadmiaru wód przez okolicznych mieszkańców i pozyskiwaniu z nich soli. Samo miasto określone zostało przez Bohusza jako „nikczemne”. Podobną opinię wystawil Karlsbadowi Poniatowski, ale warınki w łaźniach pochwalil, jako „ochędożniejsze” niż w zwiedzanych wcześniej Teplicach (s. 193). Aby zrozumieć, co miał na myśli, przytoczmy jego wspommienie z tego kurortu:

W Teplitz byłem rano w łaźni dla spróbowania, gdzie wszelako trzeba być ostrożnyın, gdyż w jedncj wodzie pozwalają wielı osobom kapać się, przez co może wszedłszy zdrowy, zostać chorym (...). Słyszałem blisko mnie pytającego się oficera, któren się po kobiecie kąpal, jakim się ona czerwonym mydlem myla? (s. 192).

Podsumowując ten z konieczności wyrywkowy i niepelny przegląd opinii Polaków o Czechach w drugiej polowie XVIII wieku, trudno pokusić się o jakieś generalizacje. Z jednej strony bowiem many do czynienia z czymś w rodzaju kompleksu niższości (w kwestiach gospodarki i stosunków spotecznych), z drugiej - z poczuciem kulturowej wspólnoty. Z pewnością można stwierdzić, że nasi podróżnicy, choć traktowali ziemie czeskie dość powierzchownie, dostrzegli parę problemów, których istnienie w owej epoce wskazują także historycy. Pojawiające się w starszych relacjach wrażenie zastoju (jak w pamiętniku Bohusza), u schylku wicku ustępuje obrazom ożywienia gospodarczego (jak u Staszica), widocznego zwlaszcza w porównaniu z ówczesną Polską. Innym problemem, dostrzeganym prawie przez wszystkich, jest kwestia języka, jego utrzymywanje się tylko w niższych warstwach spoleczeństwa. Charakterystyczny jest też zupełny brak informacji o jakiejkolwiek aktywności kulturalnej Czechów (jedynic w dziemniku Poniatowskiego 
pojawia się wzmianka o przechowywanych w zbiorach Klementimum słowiańskich „manuskryptach bardzo dawnych"). Wydaje się, że ten obraz dobrze odzwierciedla sytuację dosłownie w przededniu czeskiego odrodzenia narodowego. Warto pamiętać, że twórczość literacka niektórych z wymienionych tu podróżników (Krasickiego, Karpińskiego) odegra w tym odrodzeniu istotną rolę. Ale ich podróże do Czech lub tylko przez Czechy nie miały oczywiście na to żadnego wplywu. Krasicki, pijąc ze źródła Neubrunn w Karlsbadzie, raczej nie zdawal sobie sprawy, że już niedługo jego poezje staną się źródłem, z którego zaczerpną Antoni Jaroslav Puchmajer i Jan Kollar. 